\title{
Analysis of Constraints Faced by Farmers in Prevailing Farming Systems in Jaipur District of Rajasthan, India
}

\author{
Lal Chand Yadav*, P. S. Shekhawat and Sonu Jain \\ Department of Agricultural Economics, SKNCOA (SKNAU), Jobner, \\ Jaipur-303329, Rajasthan, India \\ *Corresponding author
}

\section{A B S T R A C T}

\begin{tabular}{l} 
Ke y w o r d s \\
$\begin{array}{l}\text { Crop, Vegetable, } \\
\text { Dairy, Enterprises, } \\
\text { Constraints }\end{array}$ \\
\hline Article Info \\
$\begin{array}{l}\text { Accepted: } \\
24 \text { October } 2020 \\
\text { Available Online: } \\
10 \text { November } 2020\end{array}$ \\
\hline
\end{tabular}

\begin{abstract}
The present investigation was conducted in Jaipur district of Rajasthan with aimed to "identify major constraints faced by farmers in different farming systems". The study revealed that four farming systems were existed in both rainfed and irrigated situations of Jaipur district viz: FS-I: Crop + Dairy $(\mathrm{C}+\mathrm{D})$, FS-II: Crop + Dairy + Vegetable $(\mathrm{C}+\mathrm{D}+\mathrm{V})$, FS-III: Crop + Dairy + Goat $(\mathrm{C}+\mathrm{D}+\mathrm{G})$ and FS-IV Crop + Poultry $(\mathrm{C}+\mathrm{P})$. The major constraints reported by household in rainfed situation for crops and dairy enterprises were inadequate irrigation facilities (61.24 mean score) and high cost of concentrates feed (64.41 mean score), respectively. While, under irrigated situation, major constraints observed in crop enterprise were lower price of farm produce (59.41 mean score) and low milk productivity of cattle (59.47 mean score) in dairy enterprise. Under poultry enterprise, high cost of feed (75.48 mean score) was observed as prime constraint under both the situations.
\end{abstract}

\section{Introduction}

Agriculture is the backbone of the Indian economy. Despite concerted industrialisation in the last five decades, agriculture occupied a pride of place in the Indian economy. The improved technology, progressiveness, innovative nature and entrepreneurial ability of the farmers could result in increased production in seventies and eighties. But, the same tempo could not be maintained now. Since, continuous input use resulted only in disproportionate returns to individual crops or cropping systems. A vast majority of available land is under dry land agriculture whose potential is not yet fully exploited. For a sustained agricultural development, the minimisation of risk in agricultural production is essential. Diversification of agriculture is the best alternative to realise this end objective.

The adoption of various farming system approaches fits well into the funnel of diversified agriculture. Farming system enterprise includes crops, livestock, poultry, fish, sericulture, vermicompost, piggery, dairy, goat, horticulture etc. A combination of one or more enterprises with cropping, when carefully chosen, planned, and executed, 
gives greater dividends than single enterprise. Farming system approach in analyzing the problems of agriculture is gaining lot of importance in recent years. Such a study, it is believed to throw light on the problems associated with different farming systems and enable the academicians and policy makers to formulate and implement appropriate policies for a balanced, integrated and overall agricultural development.

The study will also be useful for research scientists who are engaged in farming system research to observe the major constraints in farming system and to suggest the farmers for improvement on the basis of research and evaluate them critically.

\section{Materials and Methods}

The present study was conducted purposively in Jaipur district of Rajasthan, Out of sixteen tehsils of Jaipur district, two tehsils namely, Chomu and Phulera were purposively selected for the study. In both tehsils, Chomu having more proportion of irrigated area and Phulera tehsils also having more proportion of rainfed area to the total operational holding the complete list of all the villages from each selected tehsil was prepared separately, with the help of tehsil officials of the concerned tehsil.

From each list of the villages, two villages from each selected tehsil were randomly selected. Thus, constituting four villages for the detailed investigation. Then, 15 farmers from each selected village were randomly selected. In all, 60 farmers (thirty each from rainfed and irrigated farming situations) were selected for detailed study.

Primary data were collected from the selected farmers by using personal interview method with the help of pre-structured schedules. Information regarding the constraints being faced by the farmers in different enterprises were also collected. Garrets ranking technique was used to analyze the constraints perceived by the respondents in farming systems. The respondents were asked to rank the factors that limit in adoption of integrated farming systems. These orders of merit were transformed into units of scores by using the following formula:

Per cent position $=\frac{100(R i j-0.50)}{N j}$

Where,

Rij- rank given for the ith factor by the jth individual.

$\mathrm{Nj}$ - number of factor ranked by the $\mathrm{jth}$ individual.

The per cent position was converted into scores by referring to the table given by Garrett and Woodworth (1969). Then for each factor the scores of the individual respondents were added together and divided by the total number of respondents for whom score were added. These mean scores for all the factors were arranged in descending order and the most influencing factors were identified through the rank assigned.

\section{Results and Discussion}

The constraints faced by the households for different enterprises have been discussed under three sub-heads:

Constraints faced by households for crop enterprises

Constraints faced by households for dairy enterprises

Constraints faced by households for poultry enterprises 
Constraints faced by households for crop enterprises

An attempt was made to assess the constraints in crop enterprises in the study area. The major occurred constraints were enlisted and the respondents were asked to rank the constraints related to production, technology and marketing aspects of field crops and vegetable crops. The constraints faced by households for crop enterprises (field crops +vegetable crops) in rainfed and irrigated situations are shown in table -1 .

\section{In rainfed situations}

Table -1 reveals that, among thirteen constraints considered, the inadequate irrigation facilities was the major problem reported by households with a mean score of 61.24. So, this problem got first rank, followed by lower price of farm produce (mean score of 47.28), lack of desired variety (mean score of 37.84), high price of inputs (mean score of 25.94), grazing by stray animals (mean score of 23.21), disease and pest problems (mean score of 19.87), lack of market information (mean score of 16.46), lack of knowledge about improved production practices (mean score of 15.47), lack of good storage facilities (mean score of 12.25), shortage of agricultural labour during peak hours of cultivation(mean score of 10.71), high cost of labour (mean score of 8.12), lack of technical knowledge (mean score of 4.17) and lack of credit availability (mean score of 1.18).

\section{In irrigated situation}

Table -1 shows that, out of thirteen constraints, lower price of farm produce was the major problem expressed by the households with mean score of 59.41 and hence the problem assigned first rank followed by higher price of inputs (mean score of 56.71), grazing by stray animals (mean score of 49.47 score), disease and pest problems (mean score of 46.63 score), lack of desired variety (mean score of 42.27 score), lack of market information (mean score of 39.24 score), shortage of agricultural labour during peak hours of cultivation (mean score of 38.27), lack of knowledge about improved production practices (mean score of 36.77), lack of technical knowledge (mean score of 35.87), inadequate irrigation facilities (mean score of 31.21), lack of good storage facilities (mean score of 25.14), high cost of labour (mean score of 17.24) and lack of credit availability (mean score of 9.23). Similar, results were observed by Wadear (2003) and Singh and Burark (2016).

Thus, it can be concluded that in rainfed situation, inadequate irrigation facilities were found to be first rank (i.e. mean score of 61.24) among constraints reported by households. While, in irrigated situation, households opinion on lower price of farm produce was highest (i.e. mean score of 59.41) that got first rank.

\section{Constraints faced by households for dairy enterprise}

An attempt was made to assess the constraints under dairy enterprises in the study area. The major occurred constraints were enlisted and the respondents were asked to rank the constraints related to feeding, breeding, health management, milk marketing, infrastructure and technical aspects of dairy farming. The constraints faced by households for dairy enterprises in the rainfed and irrigated situations are presented in table- 2 .

\section{In rainfed situation}

Table- 2 shows that, in rainfed situation, total twelve constraints reported by households towards dairy enterprise. Among constraints, 
high cost of concentrates was the prime problem with a mean score of 64.41 , which got first rank followed by non-availability of green fodder round the year (mean score of 58.17), high cost of feed and fodder (mean score of 56.14), low milk productivity of cattle (mean score of 51.24), long dry periods in cattle (mean score of 47.44), low price of milk (mean score of 44.29), late maturity of animals (mean score of 43.17), nonavailability of dry fodder (mean score of 39.00), improper housing facilities (mean score of 36.47), lack of veterinary facilities (mean score of 34.78), lack of development programme for livestock rearing (mean score of 29.41) and lack of cold storage facilities (mean score of 26.44).

\section{In irrigated situation}

Table - 2 reveals that, in irrigated situation, total twelve constraints observed by households. Out of twelve constraints, low milk productivity of cattles was the major problem with highest mean score 59.47, so this problem assigned first rank, followed by long dry periods in cattles (mean score of 56.27), non-availability of dry fodder (mean score of 51.24), low price of milk (mean score of 49.62), high cost of concentrates (mean score of 46.82), late maturity of animals (mean score of 39.74), improper housing facilities (mean score of 36.22), high cost of feed and fodder (mean score of 43.58), lack of veterinary facilities (mean score of 42.64), non-availability of green fodder around the year (mean score of 33.44), lack of cold storage facilities (mean score of 27.44) and lack of development programme for livestock rearing (mean score of 21.74). Similar findings were reported by Nagaraju and Sankhala (2003), Nirmala and Muthuraman (2009) and Bhutia et al., (2017).

Table.1 Constraints faced by households for crop enterprises

\begin{tabular}{|c|c|c|c|c|c|}
\hline \multirow[t]{2}{*}{ S.No. } & \multirow[t]{2}{*}{ Constraints } & \multicolumn{2}{|c|}{ Rainfed situation } & \multicolumn{2}{|c|}{ Irrigated situation } \\
\hline & & $\begin{array}{l}\text { Garrett } \\
\text { Score }\end{array}$ & Rank & $\begin{array}{l}\text { Garrett } \\
\text { Score }\end{array}$ & Rank \\
\hline 1. & Higher price of Inputs & 61.24 & IV & 56.71 & II \\
\hline 2. & Inadequate irrigation Facilities & 61.24 & I & 31.21 & $\mathrm{X}$ \\
\hline 3. & Lack of technical Knowledge & 4.17 & XII & 35.87 & IX \\
\hline 4. & Lower price of farm Produce & 47.28 & II & 59.41 & I \\
\hline 5. & $\begin{array}{l}\text { Shortage of agriculture labour } \\
\text { during peak hours of cultivation }\end{array}$ & 10.71 & $\mathrm{X}$ & 38.27 & VII \\
\hline 6. & Lack of market Information & 16.46 & VII & 39.24 & VI \\
\hline 7. & Lack of desired Variety & 37.84 & III & 42.27 & V \\
\hline 8. & High cost of labour & 8.12 & XI & 17.24 & XII \\
\hline 9. & Lack of credit Availability & 1.18 & XIII & 9.23 & XIII \\
\hline 10. & $\begin{array}{l}\text { Lack of knowledge } \\
\text { about improved production } \\
\text { practices }\end{array}$ & 15.47 & VIII & 36.77 & VIII \\
\hline 11. & Lack of good storage facilities & 12.25 & IX & 25.14 & XI \\
\hline 12. & $\begin{array}{l}\text { High incidence of disease and } \\
\text { pest }\end{array}$ & 19.87 & VI & 46.63 & IV \\
\hline 13. & Grazing by stray Animals & 23.21 & $\mathrm{~V}$ & 49.47 & III \\
\hline
\end{tabular}


Table.2 Constraints faced by households for dairy enterprises

\begin{tabular}{|c|c|c|c|c|c|}
\hline \multirow{2}{*}{$\begin{array}{l}\text { S. } \\
\text { No. }\end{array}$} & \multirow[t]{2}{*}{ Constraints } & \multicolumn{2}{|c|}{ Rainfed situation } & \multicolumn{2}{|c|}{ Irrigated situation } \\
\hline & & $\begin{array}{l}\text { Garrett } \\
\text { Score }\end{array}$ & Rank & $\begin{array}{l}\text { Garrett } \\
\text { Score }\end{array}$ & Rank \\
\hline 1. & Low milk productivity of Cattles & 51.24 & IV & 59.47 & I \\
\hline 2. & Long dry period in cattles & 47.44 & V & 56.27 & II \\
\hline 3. & Late maturity of animals & 43.17 & VII & 39.74 & VIII \\
\hline 4. & High cost of concentrates & 64.41 & I & 46.82 & V \\
\hline 5. & $\begin{array}{l}\text { Lack of development } \\
\text { programme for livestock rearing }\end{array}$ & 29.41 & $\mathrm{XI}$ & 21.74 & XII \\
\hline 6. & Lack of AI and veterinary Facilities & 34.78 & $\mathrm{X}$ & 42.64 & VII \\
\hline 7. & Non- availability of dry fodder & 39.00 & VIII & 51.24 & III \\
\hline 8. & Low price for milk & 44.29 & VI & 49.62 & IV \\
\hline 9. & Lack of cold storage facilities & 26.44 & XII & 27.44 & XI \\
\hline 10. & Improper housing facilities & 36.47 & IX & 36.22 & IX \\
\hline 11. & $\begin{array}{l}\text { Non- availability of green } \\
\text { fodder round the year }\end{array}$ & 58.17 & II & 33.44 & $\mathrm{X}$ \\
\hline 12. & High cost of feeds and Fodder & 56.14 & III & 43.58 & VI \\
\hline
\end{tabular}

Table.3 Constraints faced by households for poultry enterprises

\begin{tabular}{|l|l|c|c|}
\hline S.No. & Constraints & Garrett Score & Rank \\
\hline 1. & High charge of electricity & 68.65 & IV \\
\hline 2. & Non availability of grading equipments & 67.50 & V \\
\hline 3. & Lack of credit facilities & 64.69 & VI \\
\hline 4. & Low egg price during summer & 70.00 & III \\
\hline 5. & Lack of training on poultry health Management & 61.98 & VII \\
\hline 6. & High cost of feed & 75.48 & I \\
\hline 7. & Death rate of birds is high & 71.22 & II \\
\hline
\end{tabular}

Constraints faced by households for poultry enterprises

An attempt was made to assess the constraints in poultry enterprises in the study area. The major prevailed constraints were enlisted and the poultry - respondents were asked to rank the constraints related to feeding, breeding, health management, electricity and equipment etc. The Constraints faced by farmers in poultry enterprises are shown in table- 3 .

Table - 3 depicts that, seven constraints were faced by households for poultry enterprises. Among seven constraints, high cost of poultry feed (mean score of 75.48) was the major constraints faced by the majority of farmers and hence it was assigned first rank followed by death rate of birds (mean score of 71.22), low egg price during summer (mean score of 70.00), high charge of electricity (mean score of 68.65), non-availability of grading equipments (mean score of 67.50), lack of credit facilities (mean score of 64.69) and lack of training on poultry health management (mean score of 61.98).

Following conclusions are drawn from the findings of the study: 
The major constraints under rainfed situation in crop production was inadequate irrigation facilities (with 61.24 mean score), whereas, lack of credit availability was minor problem (with 1.18 mean score).

Among constraints under irrigated situation in crop production, lower price of farm produce got first rank (with 59.41 mean score) and lack of credit availability got least rank (with 9.23 mean score) in the study area.

The major problem under rainfed situation in dairy enterprise was reported the high cost of concentrate (with 64.41 mean score) and minor problem was observed towards the lack of cold storage facilities (with 26.44 mean score) in the study area.

Among the constraints under irrigated situation in dairy enterprise, low milk productivity of cattle was assigned first rank (with 59.47mean score) and lack of cold storage facilities was reported least in rank (with 21.74 mean score).

The prime constraint under rainfed and irrigated situations in poultry enterprise was the high cost of poultry feed (with 75.48mean score) whereas minor constraint was lack of training on poultry health management (with 61.98 mean score).

\section{Recommendations}

Based on the conclusions drawn from the results of the study following policy recommendations may be suggested:

The study indicated that, under rainfed situation, major constraint faced by farmers in crop production was inadequate irrigation facilities. So, there is need for creating the awareness about the storage of rain water among the farmers through construction of farm ponds with the help of the programme and schemes run by the State Government, other agencies and NGOs.

In the study area, it was observed that, under irrigated situation, most of the farmers faced the problem of lower price of farm produce. Hence, there is a need to strengthen institutional support for procurement of farm produce at MSP and formulate appropriate produce price policies for safe guarding the interest of the farmers.

The majority of households faced with problems of high cost of concentrates and low milk productivity of cattle in rainfed and irrigated situations of the study area, respectively. Therefore, Government along with private agencies should organize efforts for improvement programmes for milk productivity of cattle and also should develop buffer stock for concentrate feed and fodder to avoid adverse farming conditions at village levels as well as block levels.

\section{References}

Bhutia, T.L., R.K. Kamal, S. Mohanty and U. Kumar (2017). Constraints analysis in the crop-livestock farming systems of small and marginal farmers of Bihar. SKUAST Journal of Research, 19(1): 92-95. Development, 16(1\&2): 57-62.

Dhaka, S.R. and B.L. Dhaka (2017). Analysis of productivity constraints faced by farmers in Tonk district of Rajasthan. International Journal of Science, Environment and Technology, 5(2): 799-805.

Garrett, H.E. and R.S. Woodworth (1969) Statistics in psychology and education. Bombay: Vakils, Feffer \& Simons Pvt. Ltd.

Hirala, J. and H.K. Verma (2004). Constraints faced by the growers in the adoption of recommended plant protection practices. Rural India, 67(6-7): 122. 
Nagaraju, D. and G. Sankhala (2003). Constraints among koyas in adoption of improved dairy farming practices. The Andhra Agricultural Journal, 50(3 \& 4): 337-341.

Nirmala, B. and P. Muthuraman (2009). Economic and constraint analysis of rice cultivation in Kaithal District of Haryana. Indian Research Journal Extension Education, 9 (1):54-57.

Pushpa, J. (2010). Constraints in various integrated farming systems. Agriculture Update, 5(3-4): 370-374.

Sharma, Y.K., G.S. Bangarva and S.K. Sharma (2008). Farming system based constraints faced by farmers. IndianResearch Journal of Extension Education, 8(1): 57-59.

Singh, Hari and S.S. Burark (2016). Constraints faced by the households in existing farming systems in Chittorgarh and Banaswara districts of Southern Rajasthan. Advances inSocial Research, 2(1): 71-76.

Wadear, P.R. (2003). Animal based farming systems for long tern sustainability in Northern Karnataka - A SocioEconomic Assessment. Ph.D Thesis, University of Agricultural Sciences, Dharwad.

\section{How to cite this article:}

Lal Chand Yadav, P. S. Shekhawat and Sonu Jain. 2020. Analysis of Constraints Faced by Farmers in Prevailing Farming Systems in Jaipur District of Rajasthan, India. Int.J.Curr.Microbiol.App.Sci. 9(11): 3646-3652. doi: https://doi.org/10.20546/ijcmas.2020.911.437 